Peer-Reviewed Article

ISSN: 2162-3104 Print/ ISSN: 2166-3750 Online

Volume 7, Issue 3 (2017), pp. 581-600

(C) Journal of International Students

http://jistudents.org/

doi: 10.5281/zenodo. 570024

\title{
An Integrated Loop Model of Corrective Feedback and Oral English Learning: A Case of International Students in the United States
}

\author{
Eun Jeong (Esther) Lee \\ Claflin University, South Carolina, USA
}

\begin{abstract}
The author in this study introduces an integrated corrective feedback (CF) loop to schematize the interplay between CF and independent practice in L2 oral English learning among advanced-level adult ESL students. The CF loop integrates insights from the Interaction, Output, and Noticing Hypotheses to show how CF can help or harm L2 learners' English practice routines. This study used a mixed method design, and the data for the CF loop were collected via qualitative open-ended survey questions and a set of forty student interviews. In the aggregate, interviewees describe a similar practice pattern and learning process and learning trajectory using their teachers' oral CF, and cite common themes and reasons for whether teachers' oral CF works or not.
\end{abstract}

Keywords: Integrated corrective feedback loop, perceived oral English improvement, advanced-level adult ESL students, independent practice in L2 oral English learning

How do students practice their corrected oral English, what kinds of strategies do they use, and how do these processes affect their oral English proficiency and their self-confidence in speaking oral English? Likewise, how can English as a Second Language (ESL) educators promote pedagogically sound and emotionally healthy learning patterns among their adult second language (L2) learners? To schematize a series of L2 acquisition patterns observed in advanced-level adult ESL students, the author in the present study proposes a qualitative integrated loop model of $\mathrm{CF}$, independent English practice, and students' oral English learning. While many activities can potentially improve students' oral English proficiency, the focus here is on formal L2 practice, as defined by DeKeyser (2007): 
"specific activities in the second language engaged in systematically deliberately, [and] with the goal of developing knowledge of and skills in the second languages” (p. 8).

Particularly since no previous studies of oral CF and L2 development have formalized this learning trajectory, the CF loop allows more rigorous investigations of how teachers' oral CF can influence learners' L2 development, and in what ways L2 learners can combine CF with independent practice to acquire target language structures. This study also contributes to scholarship on oral CF and affective variables, especially in terms of whether certain variables delay or accelerate (or even reorder) the various steps of the loop.

\section{LITERATURE REVIEW}

Oral corrective feedback (hereafter, CF) on students' oral second language (L2) production has received considerable attention over the past couple of decades. When used effectively, CF calls students' attention to their oral errors, sometimes adding explicit corrections, and can thus play a critical role in eliminating those errors (Rezaei \& Mozaffari, 2011). Many studies have demonstrated the effectiveness of CF in terms of learner uptake and target language development through teacher-learner interaction, while others have verified its characteristics and role in L2 teaching and learning (Doughty \& Varela, 1998; Havranek, 1999; Lyster \& Ranta, 1997; Ohta, 2000b; Oliver, 2000; Panove \& Lyster, 2002). There are four dominant theoretical paradigms for CF in second language acquisition (SLA) research: the Universal Grammar paradigm (Carroll, 1997, 2001; Schwartz, 1986; Schwartz and Gubala-Ryzak, 1992; White, 1991), the cognitive-interaction paradigm (see below for relevant citations), the sociocultural paradigm (Aljaafreh and Lantolf, 1994; Lantolf and Thorne, 2007; Ohta, 2000a), and conversational analysis (Hellermann, 2009; McHoul, 1990; Nakamura, 2008; Seedhouse, 1997, 2004).

Of these, cognitive-interaction theories are the most common, though research based on the sociocultural paradigm and conversational analysis has been increasing (Sheen, 2011). Specifically, cognitive theories consider oral CF as significant in learners' "acquisition of both implicit and explicit L2 knowledge” (Sheen, 2011, p. 22). Most research along these lines emphasizes one or more of three major theoretical perspectives on oral CF: the Interaction Hypothesis (Long, 1983, 1996), the Output Hypothesis (Swain, 1985, 1995, 2000), and the Noticing Hypothesis (Schmidt, 1990, 1993, 1995, 2001). Building on these contributions, the present study introduces the CF loop to integrate elements from all three hypotheses, and to confirm the close relationships between teachers' oral CF, students' selfconfidence, and their oral English improvement. 


\section{The Interaction Hypothesis}

Older models of L2 learning downplayed the importance of CF. For instance, Krashen $(1982,1985)$ argues that "comprehensible input serving as positive evidence" is enough for learners to acquire second languages (as cited in Sheen, 2011, p. 22). Therefore, in Krashen's Input Hypothesis, error correction is barely conducive to second language acquisition since it only focuses on facilitating explicit knowledge, not implicit knowledge (Sheen, 2011). However, Long $(1983,1996)$ proposed the Interaction Hypothesis to challenge this viewpoint, emphasizing the significance of interactionally modified input as interlocutors (e.g., competent speakers' and learners') negotiate meaning in communicative contexts. This negotiation, he argues, is far more conducive to language learning than merely providing comprehensible input as positive evidence. For example, in a later study Long (1996) argues that recasts, which rephrase an incorrect utterance by changing one or more of its elements without changing the meaning, connect "input, internal learner capacities, particularly selective attention, and output in productive ways” (p. 452).

Many applications of the Interaction Hypothesis have likewise focused on recasts. For instance, Doughty and Varela's (1998) study explores whether corrective feedback can be included in a content-based ESL classroom, and analyzes the effects of that feedback. The participants were two groups of sixth- and eighth-grade ESL students: the experimental group got corrective recasts during targeted communicative activities, while the control group did not. In this case, the target forms were the simple past and conditionals. These recasts consisted of two steps: repetition of the learners' utterances using rising intonation, with added stress on the verb to draw learner attention to problematic linguistic features, and then recasting with a falling intonation curve to provide the necessary target exemplar. Results showed that the experimental group showed significant positive developments in their stabilized language, while the control group showed no such progress.

Mackey and Philip's (1998) study evaluated recasts among 35 beginner and lower-intermediate level adult ESL learners. This experimental study tested two groups: one group with interactionally modified input, and the other with the same input but with intensive recasts. The findings show that interaction with intensive recasts was extremely effective for the more advanced students, more so than interaction alone, and it resulted in output development in the targeted higher-level morphosyntactic forms.

\section{The Output Hypothesis}

As a complement to the Input Hypothesis, Swain (1985, 1995, 2000) proposed the Output Hypothesis, aimed mainly at modified output during interaction (Swain, 2005, as cited in Yang, 2008). Swain claims that 
"when learners are required to produce pushed output, they are forced to engage in not only semantic processing but also syntactic processing" (Sheen, 2011, p. 24). The Output Hypothesis was derived from Swain's research experience in French immersion contexts, during which she found that immersion learners failed to acquire grammatical accuracy in terms of morphology and syntax, even though they were exposed to years of sufficient comprehensible input in communicative classrooms (Harley \& Swain, 1984; Lightbown \& Spada, 1990, 1994; Yang, 2008, as cited in Sheen, 2011).

Similarly to Long, this leads Swain to argue that comprehensible input alone is not sufficient for learners to reach grammatically accurate utterances. Her argument emphasizes that it is necessary for learners to have abundant opportunities for pushed output, in order to achieve successful language acquisition (Sheen, 2011; Yang, 2008). As she puts it, "being 'pushed' in output...is a concept parallel to that of the $\mathrm{i}+1$ of comprehensible input. Indeed, one might call this the 'comprehensible output' hypothesis” (Swain, 1985, pp. 248-9). Along similar lines, Mackey’s (2002) study points out that students' perception of being pushed was greatest when they received their teacher's corrective feedback, while it was least when they got feedback from their non-native-speaking peers.

Swain $(1993,1995)$ classifies three functions of output in second language learning. First of all, output has a noticing/triggering function. It enables learners to notice a gap between their target output and their actual output, so they recognize the limits of their linguistic knowledge (Swain, 1995). Secondly, output functions as a means of testing hypotheses about the comprehensibility and linguistic accuracy of learners' utterances, as a result of their interlocutors' feedback. Finally, output has a metalinguistic (reflective) function, which makes it possible for learners to advance "knowledge about language (metalanguage)" and enhance their awareness of the "rules of language" (Sheen, 2011, p. 24). According to Sheen, Swain's theories encourage CF "that elicits learner self-repair," and suggest that such output "is more likely to enable learners to move from comprehension to meaningful production” (Lyster, 2004; Lyster and Ranta, 1997, as cited in Sheen, 2011, p. 25).

Consequently, the opportunities CF affords for pushed output play a significant role in impelling learners to repair errors, as well as enhancing a higher rate of response (uptake), in order to improve learning potential (Sheen, 2011). Nobuyoshi and Ellis's (1993) study supports this model. In a study of low-proficiency adult ESL learners, they found that clarification requests, a type of output-prompting $\mathrm{CF}$, led to significant gains in accuracy among two of the three students in the experimental group, and to improved accuracy over time. These results show well not only the significance of the comprehensible output hypothesis, but also how it contributes specifically to 
second language acquisition.

\section{The Noticing Hypothesis}

Schmidt (1990, 1995, 2001) proposed the Noticing Hypothesis, which originated from his own experiences learning Portuguese in Brazil (Schmidt and Frota, 1986). In the Noticing Hypothesis, Schmidt maintains that L2 learning requires conscious attention to input, and that "only what is consciously noticed can be converted into intake" (Schmidt, 2001, as cited in Kim, 2004, p. 6). As Kim (2004) notes, learners' noticing of gaps in their linguistic knowledge is not a static phenomenon, and learners' internal factors (e.g., level of proficiency, L1, age, working memory, etc.) and external factors (e.g., linguistic features, task effects, contexts, etc.) influence the effectiveness of CF on L2 learning. Consequently, learners' improvement can be assessed more effectively through process-oriented measurements such as stabilized language analysis than through productoriented measurements (Doughty \& Varela, 1998). Other proponents of the Noticing Hypothesis (Ellis, 1991; Gass \& Varonis, 1994; Schmidt, 1990, 1995, 2001) also argue for the importance of corrective feedback, since it draws learners' attention to grammatical form (Kim, 2004). Specifically, this theoretical perspective asserts that corrective feedback functions as a stimulus by spurring L2 learners to "identify the gap between their erroneous utterance and the target form” (Rezaei \& Mozaffari, 2011, p. 22). In other words, both the process of noticing and awareness of those gaps are necessary for L2 learners to develop oral production, as well as for subsequent grammatical restructuring.

This emphasis on learner awareness has made the Noticing Hypothesis popular among scholars of CF. Lyster's (2004) study, for instance, uses a comparative analysis of five quasi-experimental studies to examine the effectiveness of form-focused instruction in four areas: perfect vs. imperfect past tense, the conditional mode, second-person pronouns, and grammatical gender. Almost 1,200 students ranging in age from 7 to 14 participated, distributed among 49 French immersion classrooms in Canada, primarily in content-based instructional contexts. The results of this study suggest that in terms of stabilized language features that have reached a developmental plateau, effective form-focused instruction in immersion contexts balances distribution of opportunities for noticing, language awareness, and controlled practice with feedback. Likewise, Lyster (2004) argues that instructors need to push their students to access target forms that are in competition with more readily accessible and recalcitrant stabilized language forms (Lyster, 2004).

Another relevant application of the Noticing Hypothesis is Philip's (2003) study, which probes the extent to which learners may notice native speakers' reformulations of their stabilized language grammar in the context 
of dyadic interaction. Philip's (2003) results suggest that the adult ESL learners mostly recognized the changes made to their nontargetlike utterances by way of recasts.

Song's (2007) study investigates the extent to which beginning learners actually notice the morphological and syntactic changes that occur in recasts of their nontargetlike utterances, again in the context of dyadic oral interaction. Two Korean beginning learners participated in this study, and they received demanding recasts of their morphological and syntactic errors over a period of four months. The results show that the learners noticed simple recasts to a greater extent than complex ones, and they had more success in noticing changes that targeted syntactic errors rather than morphological errors. The learners' noticing even differed among items sharing the same linguistic domain.

As these summaries show, much oral CF research has emphasized how teachers use communicative interaction to provide comprehensible input on L2 learners' errors and mistakes, how L2 learners notice the gap between their erroneous utterance and the target form, and how L2 learners generate pushed output to produce the target language successfully. However, the previous research did not gather data on L2 learners' independent attempts, based on their noticing and output, to improve their oral English proficiency. This gap significantly restricts our understanding of students' L2 learning strategies, especially since formal classroom instruction plays a relatively small part in developing L2 fluency. As DeKeyser (2007) points out, "[t]he concept of second language practice remains remarkably unexamined from a theoretical point of view. Misgivings and misunderstandings about practice abound and are often rooted in even deeper misunderstandings about what it is that language learners are supposed to learn" (p. 1). To correct these misunderstandings, this study presents a refined integrated corrective feedback loop (CFL) to locate the place of both CF and independent practice in L2 learning.The current study has two research questions:

1. What areas of perceived oral English improvement do advanced-level adult ESL students associate with their teachers' oral corrective feedback?

2. How do advanced-level adult ESL students describe and conceptualize the roles of corrective feedback and independent practice in the process of oral English learning?

\section{RESEARCH METHOD}

\section{Participants}

Sixty (60) advanced-level ESL adult students were included in this study. These participants were completing their PhDs at a large Midwestern 
university, mostly in social science or STEM fields, and were all training to be teaching assistants (TAs). They were all enrolled in the university's intensive oral English program. They came from a variety of countries: 36 were Chinese, 10 Korean, 4 Indian, 2 Japanese, 2 Taiwanese, 2 Thai, 1 Mexican, 1 Iranian, 1 Venezuelan, and 1 was from Hong Kong. All sixty were expected to teach college courses in their respective fields, in English, after completing the program. Before starting the program, each student took an institutional version of the Test of Spoken English (TSE), which measures the ability of nonnative English speakers to communicate effectively. A score of 230 on this test is required to gain TA certification, and the students in the present study all scored between 190 and 220. That is, the study participants scored better on oral proficiency, reading, vocabulary, grammar, writing, and listening than their graduate colleagues in the university's regular ESL program but their abilities were not high enough to be certified to teach. To qualify for teaching assistantships, each student had to achieve near-native levels of fluency in spoken English. Specifically, each one had to pass a mock teaching test-a 10-minute lecture to a real audience- - to demonstrate his or her oral English proficiency.

All sixty students completed a survey on their backgrounds and attitudes toward corrective feedback, and forty $(N=40)$ students agreed to participate in follow-up interview. Of the interviewed participants, 22 were Chinese, 8 Korean, 3 Indian, 2 Japanese, 2 Taiwanese, 1 Thai, 1 Venezuelan, and 1 was from Hong Kong.

\section{Setting}

This study was conducted in a focused oral English program, part of a university-affiliated ESL institute in the central United States. The program's instructors and staff members seek to improve international teaching assistants' (ITAs') oral English, to help ensure that they can teach effectively in the university. To do so, they administer placement tests to ITAs whose native language is not English, provide formal coursework as needed, and give teaching performance tests after each course to determine whether the students are ready to teach. The program has four sequenced courses, referred to here as Level 1, Level 2, Level 3, and Level 4. This study collected data from students in the Level 3 course, as the researcher's classroom observations - both those for this study and two years' worth of observations for previous studies-confirm that Level 3 students have had the most experience with CF. Based on the researcher's observation notes, teachers very frequently use immediate oral corrective feedback in the Level 3 course. In fact, CF practices are a mandatory part of the curriculum: instructors are trained to stop and correct students whenever a problem in the students' communication occurs. Students are then asked to repeat their utterances, making the suggested corrections. The ultimate goal of the 
course is to improve students' natural and readily comprehensible language, so the mostly American undergraduate student population can understand classroom lectures. Since nearly all the Level 3 instructors allowed the researcher to observe their respective classrooms (one teacher declined to be observed), the study includes CF data from a wide range of pedagogical contexts.

\section{Instruments}

The data were collected by means of two questionnaire surveys (the pre- and post-surveys) which were developed by the researcher, complemented by in-depth follow-up interview. The pre-survey was given at the end of the first week of classes, and the post-survey after an additional month of instruction. Both surveys traced the students' perceived oral English proficiency and included students' self-assessments of their phonological, lexical, grammatical, and general oral skills. These skills were measured using a 10-point Likert-type scale ranging from "beginner" to "advanced." The pre-survey also gathered data on the students' previous English learning experiences, to assist in interview planning and data analysis. Additionally, the post-survey included four open-ended questions, including one question gathering students' self-assessments of their overall oral English proficiency improvement as a result of the past four weeks of oral corrective feedback.

To ensure the validity and reliability of the questionnaire, drafts of each survey were anonymously reviewed and revised by three professors in TESOL and SLA, and by one expert on quantitative research, evaluation, and measurement. Afterward, the revised questionnaires were tested by five ITAs who had taken the Level 3 course the previous quarter. The interview questions engaged the students' qualitative survey responses. All forty students were asked to expand on their answers to the four qualitative survey questions: 1) Do you think your teacher's oral CF develops your oral English proficiency? Why or why not? 2) How does the teacher's oral CF influence your oral English improvement? 3) After getting your teacher's CF in class, how do you practice your oral English? 4) What do you think are the benefits of including oral CF in [the program]? Based on the students' responses, the qualitative interview data were analyzed and coded in accordance with four themes: becoming aware of errors and mistakes, practicing corrected oral English, improving oral English proficiency, and gaining more confidence in speaking English.

\section{Data Analysis}

To examine which areas of perceived oral English improvement advanced-level adult students experienced after receiving their teachers' oral CF (Research Question 1), results from the pre- and post-survey 
questionnaires, including phonological, lexical, grammatical, and general oral skills, were summarized using descriptive statistics. The pre-test and post-test data were also analyzed by nonparametric tests of medians, to determine if the changes were statistically significant.

Next, in order to analyze how oral CF and independent practice interacted with one another among advanced-level adult ESL students (Research Question 2), the students' responses to the post-survey's four open-ended questions were analyzed, along with the transcriptions from the interviews. Member checks were used in order to corroborate face validity, and the interview findings were coded and classified by the themes listed above. Naturally, the interviews focused on the students' strategies for practicing English outside the classroom.

\section{RESULTS}

\section{Areas of Perceived Oral English Improvement}

Students rated their oral English proficiency before and after their teachers' CF, and the self-ratings were compared using descriptive plots and statistical tests. The changes in self-rating were further explored in four major areas of phonological proficiency: phonological features, grammatical features, lexical features, and integrated oral skills.

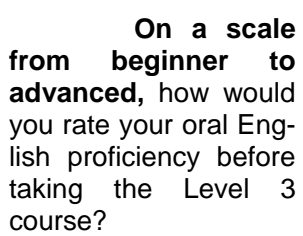

On a scale

from beginner to advanced, how would you rate your overall oral English proficiency improvement resulting from your teacher's oral corrective feedback this quarter?

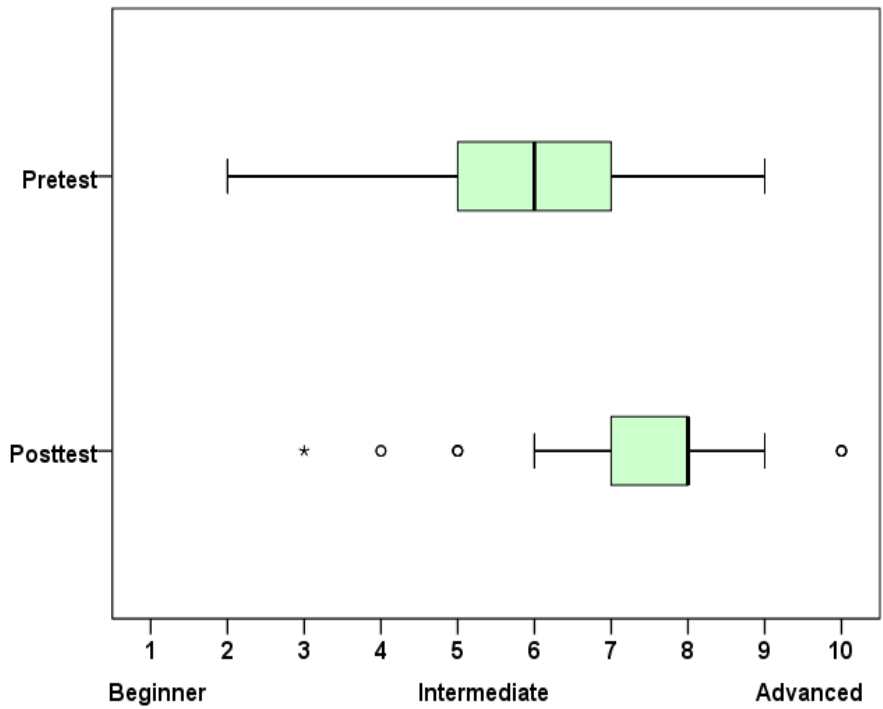

Beginner

Figure1.Distribution of self-rated overall oral English proficiency levels: pretest vs. posttest

Figure 1 displays the distributions of students' self-rated overall oral English proficiency in the pretest and posttest, using a side-by-side boxplot. 
Boxplots visualize the distribution of scores using five statistics: the minimum (the left "fence"), the first quartile (the left border of the box), the median (the middle of the box), the third quartile (the right border of the box), and the maximum (the right "fence"). Therefore, the position of the box indicates where the middle $50 \%$ of all the scores lie on the scale, and the width of the box and the distance between the fences describe the spread of the scores. Moreover, outliers in the distribution are represented by dots (minor outliers) and stars (major outliers). As shown in Figure 1, after receiving teachers' $\mathrm{CF}$, the median rating of the students' overall English proficiency increased from 6 to 8 on a scale of 1 to 10 . In the pretest, the self-ratings in the middle $50 \%$ ranged from 5 to 7 , whereas in the posttest the self-ratings in the middle $50 \%$ were either 7 or 8 . Table 1 lists the results of the statistical tests on the median change in self-rating from pretest to posttest. Since the scores are not normally distributed, two nonparametric tests, a sign test and a signed rank test, have been conducted to detect any differences in the ratings from pretest to posttest. The null hypothesis is that the median change is zero. As shown in Table 1, the median change is 1.5. With $95 \%$ confidence, the median rating will increase by somewhere between 1 and 2 from pretest to posttest. The dependent-samples sign test indicates that after receiving their teachers' oral CF during the quarter, students' self-rated oral English proficiency has increased significantly ( $p$ $<$.001). A Wilcoxon signed rank test gives the same result, suggesting that the students rated themselves significantly higher in oral English proficiency at the end of the quarter compared to the start of the quarter $(p<.001)$.

Table 1: Change in self-rated overall oral English proficiency level from pretest to posttest $(N=60)$

\begin{tabular}{|c|c|c|c|c|c|c|c|c|c|}
\hline $\begin{array}{c}+ \\
\text { change }\end{array}$ & chānge & Ties & $\begin{array}{l}\text { Median } \\
\text { change }\end{array}$ & & $6 C I$ & $t$ & $S E$ & $\begin{array}{c}\text { Stand. } \\
\text { test statistic }\end{array}$ & $p$ \\
\hline \multirow{2}{*}{47} & \multirow{2}{*}{2} & \multirow{2}{*}{11} & \multirow{2}{*}{1.500} & lower & upper & 47 & 3.500 & 6.286 & .000 \\
\hline & & & & 1.000 & 2.000 & 1205 & $\begin{array}{r}99.30 \\
4\end{array}$ & 5.967 & .000 \\
\hline
\end{tabular}

To assess the changes in self-rating between different areas of oral English proficiency from pretest to posttest, four aspects of phonological proficiency were examined: phonological features, lexical features, grammatical features, and integrated oral skills. The scores for these variables are composite measures obtained from multi-item rating scales. Table 2 lists the number of items contained in each scale, and the internal reliability (as measured by Cronbach's alpha) for each scale in the pretest and in the posttest. As shown in Table 2, the internal reliability is high for all four scales (Cronbach's alpha ranges from .925 to .966). 
Table 2: Reliability coefficients of pretest and posttest scores on four scales measuring phonological proficiency $(N=60)$

\begin{tabular}{lccc}
\hline \multirow{2}{*}{ Scale } & \multirow{2}{*}{ Number of items } & \multicolumn{2}{c}{ Cronbach's alpha } \\
\cline { 3 - 4 } & & Pretest & Posttest \\
\hline Phonological features & 16 & .960 & .966 \\
Lexical features & 4 & .925 & .930 \\
Grammatical features & 9 & .955 & .959 \\
Integrated oral skills & 7 & .961 & .966 \\
\hline
\end{tabular}

Figure 2 uses boxplots to demonstrate the distribution of self-rated pretest and posttest proficiency levels for each of the four phonological aspects. On the plot, each box represents the distribution of composite selfratings for one phonological aspect at one point in time. The boxes with lighter color indicate the pretest distributions, whereas the boxes with darker color represent the posttest distributions. As shown in Figure 2, in general the ratings have increased substantially from pretest to posttest in each of the four areas, as the distributions of self-ratings have moved towards the higher end of the scale from pretest to posttest. However, the existence of outliers in each aspect indicates that a few students did not report as much progress in phonological proficiency as their peers did.

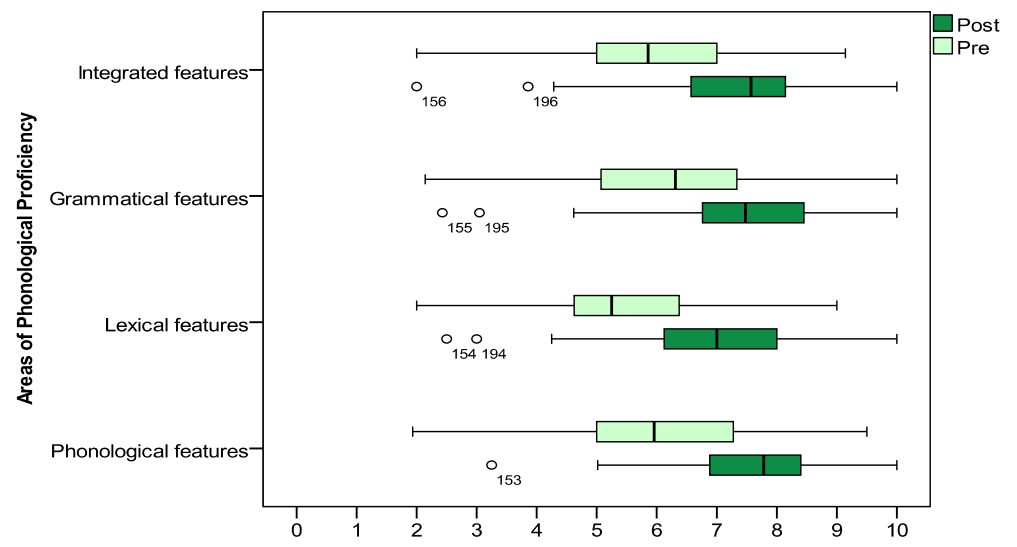

Figure 2: Distribution of self-rated phonological proficiency in four areas: pretest vs. posttest

As the existence of outliers renders the validity of tests based on normal theory questionable, dependent-samples sign tests, which do not depend on the assumption of normality, were also conducted to detect whether there is any difference in any of the four areas of phonological proficiency. As there are four dependent variables, Bonferroni correction is applied and an alpha level of 0.0125 is used for each test, so that the overall 
Type-I error rate can be controlled at the .05 level. Results of the tests are tabulated in Table 3, where each row represents the results (i.e., median change, $95 \%$ confidence interval of the change, test statistics, $p$-value, etc.) for one phonological area.

Table 3: Change in self-rated phonological proficiency in four areas from pretest to posttest: sign test $(N=60)$

\begin{tabular}{|c|c|c|c|c|c|c|c|c|c|}
\hline & \multirow{2}{*}{ 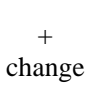 } & \multirow{2}{*}{ change } & \multirow{2}{*}{ Tie } & \multirow{2}{*}{$\begin{array}{l}\text { Median } \\
\text { change }\end{array}$} & \multicolumn{2}{|c|}{$95 \%$ CI } & \multirow{2}{*}{$t$} & \multirow{2}{*}{$S E$} & \multirow{2}{*}{$p$-value } \\
\hline & & & & & lower & upper & & & \\
\hline Phonological & 53 & 7 & 0 & 1.500 & 1.058 & 1.933 & 53 & 3.873 & .000 \\
\hline Lexical & 50 & 8 & 2 & 1.375 & 1.000 & 1.875 & 50 & 3.808 & .000 \\
\hline Grammatical & 51 & 8 & 1 & 1.214 & .762 & 1.667 & 51 & 3.841 & .000 \\
\hline Integrated & 56 & 3 & 1 & 1.429 & 1.071 & 1.786 & 56 & 3.841 & .000 \\
\hline
\end{tabular}

As shown in Table 3, all four areas of phonological proficiency feature significant increases in terms of students' self-rating $(p<.001)$. For phonological features, lexical features, and integrated oral skills, the median rating is expected to increase by around 1.4, whereas for grammatical features, the perceived proficiency level is expected to increase by 1.2. With $95 \%$ confidence, the true ratings for phonological features as well as for lexical features increased by between 1 and 1.9, the true rating for integrated oral skills increased by between 1 and 1.8, and the true rating for grammatical features increased by between 0.7 and 1.7 . In sum, the students' self-rated levels of overall oral English proficiency have increased substantially from pretest to posttest. Students have reported significantly higher self-ratings in phonological features, lexical features, grammatical features, and general oral English skills after receiving their teachers' CF during the quarter.

\section{The Integrated Corrective Feedback Loop (CFL)}

This section introduces the integrated corrective feedback loop (CFL) and explores the study's broader pedagogical implications. As described in detail below, the CFL schematizes the specific impact of CF on advanced-level adult ESL students' attempts to improve their oral English proficiency in a spoken English course, and explains how students use independent practice to supplement CF. Likewise, this section presents some ideas about how spoken English classes should be taught, and how teachers' oral CF should be used in the ESL classroom. In the aggregate, all forty interviewees described a similar learning trajectory in terms of how they balanced their teachers' oral CF and their own independent practice. This 
trajectory is schematized in the Corrective Feedback Loop.

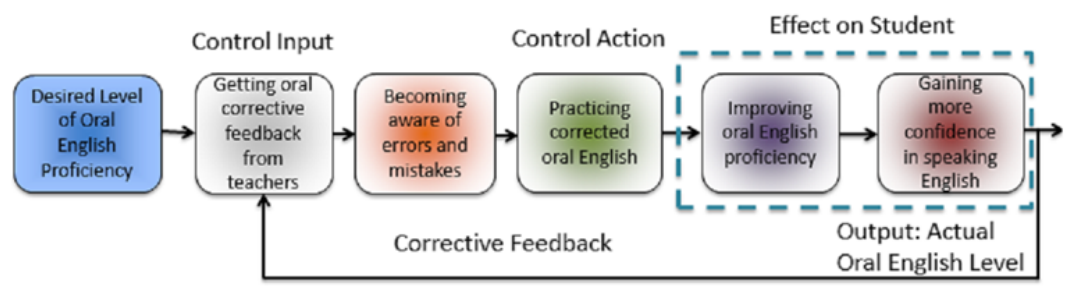

Figure 3: The Corrective Feedback Loop (CFL)

Of the forty students interviewed for this study, six described learning trajectories that were too inconsistent and idiosyncratic to include in the model. Twenty-four out of forty, though, shaped their learning trajectory by means of teachers' oral CF, as indicated in Figure 3. However, ten other students switched the order of two elements: "Gaining more confidence in speaking English" and "Improving my oral English Proficiency." This pattern suggests that the precise order of gaining confidence and improving oral proficiency may depend on individual differences among students, perhaps including multiple affective variables.

\section{CFL Components}

The CFL system has the following components:

1. Reference Value: the desired level of oral English proficiency we want to achieve.

2. Controller: applies a control action over the plant (the student) to drive the output (oral English level) to the desired reference value.

3. Plant (the student): the subject that the instructor seeks to "control" so that he or she achieves the desired reference value.

4. Feedback loop: uses the output (oral English level) to obtain the necessary information to compare the actual oral English level with the desired proficiency level.

The CFL could potentially be limited to fixing a single error (e.g., mispronouncing a particular word, a single component of the student's English proficiency), which would create a single-input and single-output system. However, since language proficiency requires multiple components, it is more helpful to think of multi-input (e.g., different instances of CF) and multiple outputs (e.g., new utterances in English).

\section{How does the CFL work?}

First, the student's existing level of proficiency is measured by a diagnostic test or an interview. Based on these results, the desired level of 
oral English proficiency is selected by an instructor or program administrator. For instance, a student with a poor level of English should be placed in a beginner class, so that the correct "control input" and "control action" can be taken.

Second, in accordance with the student's actual oral English level, the instructor provides corrective feedback (control input) on the student's errors. By using the information given by the feedback, the student starts becoming aware of his or her errors. The student will use this information to plan and carry out specific actions.

Third, the student starts taking some control actions by means of practicing the corrected oral English. This practice affects the student's English ability and emotions toward speaking English. This model assumes that the control actions are applied constantly; therefore, positive effects should eventually be obtained.

Fourth, the student starts to perceive positive effects by means of improving his/her oral English proficiency and gaining more confidence in speaking English. These two processes are interconnected, because as students improve they start gaining confidence, and as they gain confidence they become more willing to improve their oral English.

Fifth, the student reaches a new outcome or creates new output based on his or her new oral English level. If the student's new output is acceptable to the instructor, the CFL ends since the target fluency level has been reached. However, if the student's new output is not acceptable to the instructor, the student gets more CF from the instructor and returns to the error noticing step. Depending on the student's expectations, this new feedback may introduce a range of emotions, including frustration, excitement, motivation, and confidence. All this new information feeds back into the corrective feedback loop.

Sixth, the teacher or instructor uses the student's updated oral English level to provide further oral feedback to the student. In this way, the student is capable of assessing the level of her/his oral English proficiency. This information returns feedback to the first step of the loop, in order to obtain a closed-loop feedback control process.

\section{DISCUSSION}

\section{Independent Practice and Oral English Improvement}

DeKeyser (2007) asserts that though various components of "teaching, practicing, and providing feedback" have received sustained scholarly attention, "what exactly the ideal point is on the analytic/synthetic dimension of curriculum design, and what this implies for practice activities, is still far from resolved, especially in the foreign language context” (p. 9). The integrated corrective feedback loop presented in the current study helps resolve those questions, as it allows us to examine relationships between 
teachers' oral CF, affective variables, and students' oral English improvement more precisely. The results presented here show that in order to improve their English oral proficiency students must supplement their teachers' CF with their own practice and efforts. Specifically, the CF loop shows significant interactions among teachers' input (oral CF), students' noticing, students' output, students' further practice based on their noticing and output, and students' actual English improvement and increased selfconfidence.

Similarly, the CF loop examines how and when teachers' oral CF affects a series of interrelated SLA cognitive processes. Most importantly, it recognizes the centrality of students' independent practice in L2 acquisition, rather than assuming that most or all language learning must happen in the classroom. The following interview excerpts demonstrate the participants' attitudes toward CF and oral English practice, and why they think both are important:

Practice is important, because first, if you never speak, how can you improve? And second, it's just the way you learn something. Especially if you have a problem or mistake in your speaking, you've had it for quite a long time, and it's already become kind of like a habit in your mind. The only way you can get rid of that is to do a different thing, practicing it for an amount of time; otherwise, you can never fix it (Participant 14's personal interview, May 25, 2012).

I already studied English for a long time, more than 10 years, but it's not perfect. Even though it's poor, I think I know mostly about English grammar, reading, vocabulary, and writing. But speaking is totally different. And when I write something, I can fix and I can change the sentence whenever I want. But in conversation or in speaking, I have just a few seconds to respond. So that makes me use the wrong grammar or wrong sentences, wrong intonation, stress, and pronunciation. So when I get feedback from other people about my error, I fix that error, and then I practice the corrected pronunciation, phrases, or sentences as much as I can until I can speak them out naturally (Participant 5's personal interview, May 23, 2012).

Most of the interviewed students argued that effective practice requires a conscious awareness of the differences between their own errors and the modified forms or pronunciation their teachers and textbooks present. In order to get familiar with the modified forms and patterns, the students continuously practiced the corrected words and phrases until they 
spoke them automatically or unconsciously. In other words, "output practice that leads learners to notice gaps in their interlanguage systems, test their existing knowledge, reflect consciously on their own language, and process language syntactically is expected to be the most beneficial for L2 development” (Muranoi, 2007, p. 59). The following interview excerpts show how the students' successful practice strategies affect their cognitive processes, and likewise reveal their thoughts on the roles and functions of practicing oral English:

If you don't practice it, you can't be [fluent]-I don't think I'm getting $100 \%$ of my teacher's feedback, but I pick up things which should be really important to improve my pronunciation and everything. As I told you, words like "good," that kind of thing, and "consumer science." I just pick up things which are really important for me. And if I don't practice over and over, it's not going to come out naturally. After practicing it, you have to speak in front of other people, or it's not going to come out naturally. Although you care about it, it's not going to be yours. Especially if you are in a setting which is not English class, like if you do a presentation in other classes, if it's not yours, you're not going to care about your pronunciation as much as you do in English classes. So if you don't make it yours, then it's not going to be improved much (Participant 20's personal interview, May 26, 2012).

How can I say about the roles of practice? I think practice is important. You need practice, because you know some patterns, you know the right patterns, but if you don't practice it, you just know it. Or maybe when somebody is speaking, if they are wrong, you can tell. But if you don't practice when you speak, the next time you will still make the same mistake. And you know that. But how can you achieve that, so you never make the same mistake? You need to practice to make the muscles of your mouth stronger, to-how can I say that?-to form your pattern (Participant 19's personal interview, June 7, 2012).

These results confirm that practice "plays an important role in improving performance so that it becomes more rapid and stable. This occurs when components of a skill become automatized, which then liberates attentional resources for use in higher-level processing” (Ranta \& Lyster, 2007, p. 147). Overall, the present study underscores the importance of L2 learners' investment in practice time and strategies, allowing them to apply their studies and their teachers' CF to develop their oral English proficiency outside the classroom. By locating the place of both CF and 
independent practice in L2 learning, this study suggests a broad perspective on CF that shows a common and practical trajectory for advanced-level adult ESL students’ English learning.

\section{LIMITATIONS AND FURUTHER RESEARCH}

The present study's theoretical framework also creates some limitations. As mentioned in the literature review, this study focuses on the Interaction Hypothesis, the Output Hypothesis, and the Noticing Hypothesis to examine the associations between CF, self-confidence, and oral English improvement among advanced ESL students in a spoken English course. Unlike most of the previous studies discussed in the literature review, whose target structures emphasized grammatical knowledge and features, the present study focuses on oral communication skills, and specifically on how advanced-level adult ESL students improved phonological features of their oral English proficiency.

Although these students certainly benefited from their instructors' CF on grammatical errors and structures, both the CF and the course in general sought to improve the students' command of functional grammar for the specific purpose of oral communication skill development. As a result, the results of the present study might be different from studies which examined the extent to which certain types of CF influenced the effects of L2 learning and acquisition on various grammatical forms and structures.

More importantly, as the corrective feedback loop demonstrates, CF forms only part of L2 learners' efforts to improve their oral English, a process that often stretches over several years. Attention to these broader processes could measure the long-term effectiveness of oral CF, to investigate how being aware of their errors and mistakes has an effect on students' long-term personal efforts and practices to develop their oral English proficiency.

\section{REFERENCES}

Aljaafreh, A., \& Lantolf, J. (1994). Negative feedback as regulation and second language learning in the zone of proximal development. The Modern Language Journal, 78, 456-483.

Carroll, S. (1997). The irrelevance of verbal feedback to language learning. In L. Eubank, L. Selinker, \& M. Sharwood Smith (Eds.), The current state of interlanguage (pp. 73-88). Amsterdam, The Netherlands: John Benjamins.

Carroll, S. (2001). Input and evidence: The raw material of second language acquisition. Amsterdam, The Netherlands: John Benjamins.

DeKeyser, R. M. (2007). Introduction: Situating the concept of practice. In R. M. DeKeyser (Ed.), Practice in a second language (pp. 1-18). Cambridge, NY: Cambridge University Press.

Doughty, C., \& Varela, E. (1998). Communicative focus on form. In C. Doughty \& J. Williams (Eds.), Focus on form in classroom second language acquisition 
(pp.197-261). Cambridge: Cambridge University Press.

Ellis, R. (1991). The interaction hypothesis: A critical evaluation. In E. Sadtono

(Ed.), Language acquisition and the second/foreign language classroom. Singapore: RELC.

Gass, S. M., \& Varonis, E. M. (1994). Input, interaction and second language production. Studies in Second Language Acquisition, 16, 283-302.

Havranek, G. (1999). The effectiveness of corrective feedback: Preliminary results of an empirical study. Acquisition et interaction en language étagère: Proceedings of the Eighth EUROSLA Conference 2, 189-206.

Hellermann, J. (2009). Practices for dispreferred responses using no by a learner of English. IRAL, 47, 95-126.

Kim, J. H. (2004). Issues of corrective feedback in second language acquisition. Teachers College, Columbia University Working papers in TESOL \& Applied Linguistics, 4(2), 1-24.

Krashen, S. (1982). Principles and practice in second language acquisition. Oxford: Pergamon.

Krashen, S. (1985). The input hypothesis: Issues and implications. London: Longman.

Lantolf, J., \& Thorne, S. (2007). Sociocultural theory and second language learning. In B. VanPatten \& J. Williams (Eds.), Theories in second language acquisition: an introduction (pp. 197-220). Mahwah, NJ: Lawrence Erlbaum.

Long, M. H. (1983). Native speaker/non-native speaker conversation in the second language classroom. In M. Clarke \& J. Hanscombe (Eds.), On TESOL '82. Washington, D. C.: TESOL.

Long, M. (1996). The role of the linguistic environment in second language acquisition. In W. C. Ritche \& T. K. Bhatia (Eds.), Handbook of second language acquisition (pp.413-468). San Diego, CA: Academic Press.

Lyster, R. (2004). Research on from-focused instruction in immersion classrooms: Implications for theory and practice. French Language Studies, 14, 321-341.

Lyster, R., \& Ranta, L. (1997). Corrective feedback and learner uptake: Negotiation of form in communicative classrooms. Studies in Second Language Acquisition, 19, 37-66.

Mackey, A. (2002). Beyond production: learners' perceptions about interactional processes. International Journal of Educational Research, 37, 379-394.

Mackey, A., \& Philip. J. (1998). Recasts, interaction and interlanguage development: Are responses red herrings? The Modern Language Journal, 82, 338-356.

McHoul, A. W. (1990). The organization of repair in classroom talk. Language in Society, 19, 349-377.

Muranoi, H. (2007). Out practice in the L2 classroom. In R. M. DeKeyser (Ed.), Practice in a second language (pp. 51-84). Cambridge, NY: Cambridge University Press.

Nakamura, I. (2008). Understanding how teacher and student talk with each other: An exploration of how repair displays the co-management of talk-ininteraction. Language Teaching Research, 12, 265-283.

Nobuyoshi, J., \& Ellis, R. (1993). Focused communication tasks and second language acquisition. ELT Journal, 47, 203-210. 
Ohta, A. (2000a). Rethinking interaction in SLA: Developmentally appropriate assistance in the zone of proximal development and the acquisition of L2 grammar. In J. Lantolf (Ed.), Sociocultural theory and second language learning (pp. 51-78). Oxford: Oxford University Press.

Ohta, A. (2000b). Rethinking recasts: A learner-centered examination of corrective feedback in the Japanese classroom in J. K. Hall and L. Verplaetse (Eds.): The construction of second and foreign language learning through classroom interaction. Mahwah, NJ: Erlbaum, pp. 47-71.

Oliver, R. (2000). Age differences in negotiation and feedback in classroom and pairwork. Language Learning, 50, 119-151.

Panove, I., \& Lyster, R. (2002). Patterns of corrective feedback and uptake in an adult ESL classroom. TESOL Quarterly, 36, 573-593.

Philip, J. (2003). Constraints on noticing the gap: Nonnative speakers' noticing of recasts in NS-NNS interaction. Studies in Second Language Acquisition, 25, 99-126.

Ranta, L., \& Lyster, R. (2007). A cognitive approach to improving immersion students' oral language abilities: The awareness-practice-feedback sequence. In R. M. DeKeyser (Ed.), Practice in a second language (pp. 141-160). Cambridge, NY: Cambridge University Press.

Rezaei, S., Mozaffari, F. (2011). Corrective feedback in SLA: Classroom practice and future directions. International Journal of English Linguistics, 1(1), 2129.

Schmidt, R. (1990). The role of consciousness in second language learning. Applied Linguistics, 11, 129-58.

Schmidt, R. (1993). Awareness and second language acquisition. Annual review of Applied Linguistics, 13, 206-26.

Schmidt, R. (1995). Consciousness and foreign language learning: A tutorial on the role of attention and awareness in learning. In R. Schmidt (Ed.), Attention and awareness in foreign language learning. Honolulu: University of Hawaii Press.

Schmidt, R. (2001). Attention. In P. Robinson (Ed.), Cognition and second language instruction (pp. 3-32). Cambridge, UK: Cambridge University Press.

Schwartz, B. (1986). The epistemological status of second language acquisition. Second Language Research, 2, 120-159.

Schwartz, B., \& Gubala-Ryzak, M. (1992). Learnability and grammar reorganization in L2A: Against negative evidence causing the unlearning of verb movement. Second Language Research, 8, 1-38.

Seedhouse, P. (1997). The case of the missing "no": The relationship between pedagogy and interaction. Language Learning, 47, 547-583.

Seedhouse, P. (2004). The organization of repair in language classrooms. In Young, R. (Ed.), the international architecture of the language classroom: A conversation analysis perspective (pp. 141-180). Language Learning Monograph Series.

Sheen, Y. (2011). Corrective feedback, individual differences and second language learning. New York: Springer.

Song, S. (2007). Beginning ESL learners' noticing of morphological and syntactic changes in recasts. Teachers College, Columbia University Working Papers 
in TESOL \& Applied Linguistic, 7, 1-25.

Swain, M. (1985). Communicative competence; some roles of comprehensive input and output in its development. In S. Gass \& C. Madden (Eds.), Input in second language acquisition (pp. 235-53). Cambridge, MA: Newbury House.

Swain, M. (1993). The output hypothesis: Just speaking and writing aren’t enough. Canadian Modern Language Review, 50, 158-164.

Swain, M. (1995). Three functions of output in second language learning. In G.Cook, \& B. Seidlhoffer (Eds.), Principles \& practice in applied linguistics: Studies in honor of H. G. Widdowson (pp. 125-44). Oxford: Oxford University Press.

Swain, M. (2000). French immersion research in Canada: Recent contributions to SLA and Applied Linguistics. Annual Review of Applied Linguistics, 20, 199212.

White, L. (1991). Adverb placement in second language acquisition: some effects of positive and negative evidence in the classroom. Second language Research, 7, 133-161.

Yang, Y. (2008). Corrective feedback and Chinese learners' acquisition of English past tense. Doctoral dissertation. McGil University.

EUN JEONG (ESTHER) LEE, Ph.D., is the Director of the Intensive English Language Program and an Assistant Professor of English and Foreign Languages at Claflin University. Her specific research interests include corrective feedback, the affective elements of L2 pedagogy, emotion and learning, informal English conversations, ESL learning patterns, curriculum development, and ESL program management. Email: eulee@claflin.edu. 